\title{
Ariel Merari, 2010, Driven to Death : Psychological and Social Aspects of Suicide Terrorism, Oxford, Oxford University Press, 315 p.
}

Domenico Tosini

\section{(2) OpenEdition}

Journals

Édition électronique

URL : http://journals.openedition.org/ress/1241

DOI : $10.4000 /$ ress. 1241

ISSN : 1663-4446

Éditeur

Librairie Droz

\section{Édition imprimée}

Date de publication : 15 juin 2012

Pagination : 270-272

ISBN : 978-2-600-01613-1

ISSN : 0048-8046

\section{Référence électronique}

Domenico Tosini, « Ariel Merari, 2010, Driven to Death : Psychological and Social Aspects of Suicide Terrorism, Oxford, Oxford University Press, 315 p. », Revue européenne des sciences sociales [En ligne], 50-1 | 2012, mis en ligne le 06 juin 2012, consulté le 22 septembre 2020. URL : http:// journals.openedition.org/ress/1241; DOI : https://doi.org/10.4000/ress.1241

Ce document a été généré automatiquement le 22 septembre 2020

(C) Librairie Droz 


\title{
Ariel Merari, 2010, Driven to Death : Psychological and Social Aspects of Suicide Terrorism, Oxford, Oxford University Press, $315 \mathrm{p}$.
}

\author{
Domenico Tosini
}

With Driven to Death, Ariel Merari, who has studied terrorism for more than thirty years, offers a crucial advance in our understanding of the causal mechanisms behind suicide missions thanks to groundbreaking research on a sample of incarcerated Palestinian would-be suicide bombers - a suicide terrorist attack being defined as "a situation in which a person intentionally kills himself (or herself) for the purpose of killing others in the service of a political or ideological goal" (Chapter 1, p. 9). The presentation of results of this investigation (Chapter 5) is preceded by an overview on main suicide terrorism campaigns (Chapter 2), demographic characteristics of bombers (Chapter 3) and interviews with attackers' families (Chapter 4). Readers will find data on suicide bombings, including a year-by-year accounting of 2,622 suicide attacks (2,937 bombers) from 1981 to 2008 (Chapter 2, Figure 2.1) and a country-by-country accounting of these events (Table 2.1). Major suicide campaigns are also examined - in Lebanon, Israel, Iraq, and Afghanistan - for their impact on the development of the phenomenon. Demographic information on suicide terrorists (Chapter 3) shows a general profile : $95 \%$ were male ; $89 \%$ under age 30 years (and $69 \%$ under 25 ) ; $82 \%$ single; and $91 \%$ Muslim. Interviews with families of 34 Palestinian suicide bombers (Chapter 4) document, among other things, a variety of reactions. Almost all families revealed both grief at their sons' suicide missions and pride in them. This duality created an emotional conflict and cognitive dissonance from which sometimes emerged an overt criticism of suicide bombings as futile.

2 The centerpiece of the book is an in-depth analysis of fifteen incarcerated Palestinian would-be suicide bombers compared with a control group of twelve terrorists imprisoned for offences unrelated to suicide terrorism (Chapter 5) - both subjected to 
variety of tests and interviews with clinical psychologists. Would-be suicide bombers manifested two personality patterns - a dependent-avoidant personality $(60 \%$ as opposed to $16.7 \%$ of the controls) and an impulsive-unstable personality (26.7\% as opposed to $66.7 \%$ in the control group) - and suicidal tendencies ( $40 \%$, with no symptoms in the control group). According to the author, "data converged on a predominant type of suicide bombers. Most of the would-be suicides were shy, socially marginal, followers rather than leaders. Many were loners and outsiders, with a history of failure in school, and harbored the feeling of having disappointed their parents. More than one third has suicidal tendencies, which may have played an important role in their willingness to become 'martyrs'. As a group, their personality features were markedly different from the controls." (Chapter 5, p. 119). This analysis is strictly linked to a subsequent discussion of suicide theories (Chapter 8), in which the author contests reductionist approaches applying descriptions and explanations for "ordinary" suicides to suicide terrorists. Risk factors associated with the two categories are not the same. Suicidal dispositions were not diagnosed in the majority $(60 \%)$ of the would-be attackers: "most suicide bombers in our sample did not undertake the mission because they wished to die so as to put an end an intolerable mental pain, but because their personality characteristics [especially a dependent-avoidant personality] made them more susceptible to external influence." (Chapter 8, p. 222).

3 Following this analysis of bombers' profiles, the book presents results from interviews with fourteen regional commanders of Palestinian armed groups involved in suicide attacks (Chapter 6). This section helps shed light on further psychological aspects of the phenomenon and decision-making related to recruitment and preparation of attackers. Most organizers revealed no signs of willingness to volunteer for martyrdom. As for recruitment of attackers, the organizers' main preferences were for young and unmarried candidates driven by religious beliefs and nationalist motivations. A crucial role emerges for videotaped last wills used not only as propaganda instruments but also as rituals for strengthening recruits' commitment. Data on Palestinian public opinion about suicide attacks on Israeli civilians are also examined (Chapter 7). Communities' attitudes exert great influence on both armed groups and potential bombers. Factors promoting public support for suicide attacks include Islamic radicalism and events responsible for casualties among Palestinians. It is also clear, however, from other contributions that "public support for suicide attacks is, in itself, insufficient for generating actual suicides." (Chapter 7, p. 183). Other conditions are the perception of existential interests at stake, the justification of martyrdom by media and authoritative figures, and organizations recruiting and preparing the attackers.

4 After the discussion of suicide theories (Chapter 8) already mentioned, a concluding, critical assessment is made of current theories of suicide terrorism. Political grievances, tactical advantages, strategic objectives, intergroup competitions, culture and religion, as well as group processes and social networks, are all viewed as contextual factors, which are certainly important but "alone [...] insufficient to explain why, given the same situation, certain people end up as suicide bombers [...], whereas other do not. [...]. The rarity of suicide attackers seems to warrant the assumption that they have distinctive personality characteristics." (Chapter 9, p. 243).

5 Given the small number of interviewees (all Palestinian), questions can be raised about the opportunity to generalize results related to suicide bombers' profiles. Looking at the state of the art in the field concerning suicide terrorism, however, Merari has 
replaced nothing with something. There can be no doubt that future investigations will build on this book. It is a crucial challenge to the conventional wisdom that suicide bombers are psychologically normal. Many scholars tend marginalize psychological explanations, underlining the primary role of political and ideological conditions of (suicide) terrorism. As Merari demonstrates, a more comprehensive approach to political violence cannot exclude personality traits as causal factors. His contribution is also a confutation of those theories assuming that bombers' motivations inevitably reflect political and religious values and goals propagandized by armed groups. Not only suicide tendencies but also certain psychological mechanisms associated with personality patterns, as diagnosed by Merari, show that potential bombers can be driven by desires and emotions primarily focused on their private lives, with no or little connection with a collective, religious o political cause. In this sense, overall the book is successful in providing a more adequate articulation of our view of the phenomenon. It forms a very important basis for new empirical research on (suicide) terrorism, which can be successful only if it is inspired by a genuine multidisciplinary perspective.

\section{AUTEURS}

\section{DOMENICO TOSINI}

Università di Trento - Dipartimento di Sociologia e Ricerca sociale 